\title{
Idiopathic granulomatous mastitis: a diagnostic challenge
}

\author{
Pandey D. ${ }^{1}$, Syed A. ${ }^{2}$, Ravi B. ${ }^{3}$, Chaudhary N. ${ }^{4}$, Kapoor A. ${ }^{5}$, Mehrotra S. ${ }^{6}$ Gupta P. $^{7}$, Pranoy ${ }^{8}$ \\ ${ }^{1}$ Dr Divya Pandey, Integrated Breast Care Clinic, AIIMS Rishikesh, ${ }^{2}$ Dr Anjum Syed, ${ }^{3}$ Dr Bina Ravi, ${ }^{4}$ Dr Nilotpal \\ Chowdhury, ${ }^{5}$ Dr Aakriti Kapoor, ${ }^{6}$ Dr Surabhi Mehrotra, ${ }^{7}$ Dr Priyanka Gupta, ${ }^{8}$ Dr Pranoy, Department of Pathology, AIIMS, \\ Rishikesh, India
}

Corresponding Author- Dr. Divya Pandey MBBS, DNB -Radiodiagnosis, PDCC Fellow - Breast Imaging (IBCC, AIIMS Rishikesh) E-mail: divya.pandey395@gmail.com

\begin{abstract}
Introduction: Idiopathic granulomatous mastitis is an uncommon and benign inflammatory breast disease that usually occurs in young women of childbearing age. Most common presentation is a slowly growing breast mass that is hard in consistency and can greatly mimic breast cancer. Mammographic and ultra-sonographic findings are non- specific and usually mimic malignant masses leading to higher BIRADS grading in reports. The only way to reach a definitive diagnosis is by histopathological diagnosis. Material \& Methods: In the present study eight patients were presented to The Integrated Breast Care Centre (IBCC) department of AIIMS Rishikesh with breast lump or nipple discharge during January 2019 to June 2019. All the patients underwent mammography and ultrasonography followed by FNAC or Biopsy of the lesion as findings were mimicking malignant etiology. Results: On HPE all the patients showed features of granulomatous inflammation and diagnosis of idiopathic granulomatous mastitis was made. TB was excluded by CBNATT (Cartridge Based Nucleic Acid Amplification Test) examination of the aspiration cytology samples. To our knowledge, such a report is the first of its kind to address this topic in this region. Conclusion: In a young child-bearing age group female presenting with breast mass a differential of idiopathic granulomatous mastitis should also be considered. The clinicians as well as radiologists should be aware of this entity so that appropriate management may be done.
\end{abstract}

Key words: Idiopathic granulomatous mastitis, benign inflammatory breast disease, Benign breast disease

\section{Introduction}

Idiopathic granulomatous mastitis (IGM) is an uncommon and benign inflammatory breast disease that usually occurs in young women of childbearing age.

Although initially described nearly 30 years ago, the number of cases in the literature remains small. The clinical diagnosis is difficult with clues from the history, but clinical awareness that this condition can mimic breast cancer in all aspects of the triple assessment process should arouse suspicion. It has been frequently misdiagnosed as breast carcinoma, and many times treated with co-therapy or mastectomy.

The real incidence of Idiopathic granulomatous mastitis is unknown, with only a few hundred cases reported in the literature $[1,2]$.

Although Idiopathic granulomatous mastitis usually appears within 6 years after pregnancy, the lesion may develop up to 15 years postpartum. Although most GM cases show association with lactation and pregnancy, a minority of cases have been linked to hyper- prolactinemia caused by either dopamine antagonist medications or with intracranial lesions, such as pituitary adenoma.

Most common presentation is a slowly growing breast mass that is hard in consistency and can greatly mimic breast cancer. Mammographic and ultra-sonographic findings are non- specific and usually mimic malignant masses leading to higher BIRADS grading in reports. Neither mammography nor Doppler sonography plays a significant role in the differential diagnosis of granulomatous mastitis versus or carcinoma. Gray-scale sonography shows findings specific for granulomatous mastitis in some cases, but all cases require histopathologic confirmation for final diagnosis. The only way to reach a definitive diagnosis is by histopathological diagnosis. Non-caseating and multiple well-defined granulomas distorting the normal breast lobules are the typical features of IGM in histopathological examination. 
Original Research Article

The optimal treatment approach for IGM has not been established, research limited by the low frequency of the diagnosis. Surgical intervention in the form of wide surgical excision was the mainstay of treatment before 1980 and is still performed depending on local expertise and preference. In some rare cases, mastectomy is performed with breast reconstruction $[3,4]$.

As it is an uncommon disease with nonspecific presentation, it is frequently undiagnosed or misdiagnosed leading to either under treatment or sometimes unnecessary interventions including mastectomy. In the present series, a case series of idiopathic granulomatous mastitis were reported to add to the existing literature. The clinical presentation, treatment, and pathological findings are described, along with literature review and discussion. To our knowledge, such a report is the first of its kind to address this topic in this region.

\section{Material and Methods}

Setting- All eight women presented to the integrated Breast Care Centre AIIMS, Rishikesh with complains of breast lump with/without discharge. All patients underwent ultrasonography (US) examination and mammography followed by US-guided Biopsy except a 25-year lactating female where only FNAC correlation was done.

Type and Duration of study- It was a prospective observational study conducted between 1 January 2019 and 30 June 2019 in IBCC, AIIMS Rishikesh.

Sampling- Sampling was random with all patients presenting with breast lump in IBCC outpatient department.

Inclusion criteria- All patients with unilateral breast lump with histopatholoically proven granulomatous inflammation without any identifiable organism and absence of features of malignancy.
Exclusion criteria- All patients in whom microbiological or pathological cause was found like tuberculosis, other bacterial mastitis or features consistent with malignancy.

Data collection and analysis- Standard mammography views were taken for bilateral breasts in cranio-caudal and medio-lateral projections on "Hologic Dimensions" Mammographic system with tomography and automatic dose adjustment and an automated compression device.

After the patients were examined mammographically, they would be taken for ultrasonography unit where the examination was performed using a Mindray Ultrasound system equipped with a $5-10 \mathrm{MHz}$ linear probe. Scanning was done in supine and lateral decubitus positions in both radial and anti-radial directions. Both axillae were also scanned for evaluation of the lymph nodes.

FNAC was done was using $23 \mathrm{G}$ needles and biopsies were done using $14 \mathrm{G}$ automatic biopsy gun. Both procedures were done under real time ultrasound guidance.

On HPE all the patients showed features of granulomatous inflammation and diagnosis of idiopathic granulomatous mastitis was made. Tubercular etiology was ruled out using CBNAAT (Cartridge Based Nucleic Acid Amplification Test)) examination.

Scoring system- Breast Imaging Reporting and Data System (BIRADS) was used for reporting all sonography and mammography findings.

Ethical considerations- The study was approved by Ethical and Scientific committee of the institute. All the patients were included after written informed consent. All the patients were included after written informed consent.

\section{Results}

Table-1 Clinical, Imaging and Pathological findings with Treatment and Follow up.

\begin{tabular}{|c|c|c|c|c|c|}
\hline $\begin{array}{c}\text { Age } \\
\text { (Years) }\end{array}$ & $\begin{array}{c}\text { Clinical } \\
\text { presentation }\end{array}$ & $\begin{array}{c}\text { Radiological } \\
\text { findings }\end{array}$ & HPE/Cytology & $\begin{array}{c}\text { Duration } \\
\text { from } \\
\text { lactation }\end{array}$ & $\begin{array}{c}\text { Treatment \& } \\
\text { follow-up }\end{array}$ \\
\hline 42 & $\begin{array}{c}\text { Breast Lump } \\
\text { for 1 month }\end{array}$ & $\begin{array}{c}\text { BIRADS-5, } \\
\text { Highly } \\
\text { suggestive of } \\
\text { malignancy } \\
>95 \%\end{array}$ & $\begin{array}{c}\text { Chronic lobulitis } \\
\text { with granuloma } \\
\text { formation and } \\
\text { epithelioid cells, } \\
\text { lymphocytes and } \\
\text { histiocytes. }\end{array}$ & $\begin{array}{c}\text { 6years } \\
\text { tablet for 21 days, } \\
\text { tapered to 10 and } \\
\text { 5mg. }\end{array}$ & $\begin{array}{c}\text { Patient is symptom } \\
\text { free till date. } \\
\text { (Duration of follow } \\
\text { up- 4months }\end{array}$ \\
\hline
\end{tabular}


Original Research Article

\begin{tabular}{|c|c|c|c|c|c|}
\hline 40 & $\begin{array}{l}\text { Breast Lump } \\
\text { for } 1.5 \text { months }\end{array}$ & $\begin{array}{l}\text { BIRADS-4C, } \\
\text { high suspicion } \\
\text { for malignancy } \\
\quad(50-95 \%)\end{array}$ & $\begin{array}{l}\text { Well -formed } \\
\text { granulomas } \\
\text { comprising of } \\
\text { epithelioid cells, } \\
\text { lymphocytes and } \\
\text { histiocytes s/o } \\
\text { granulomatous } \\
\text { mastitis. }\end{array}$ & 3 years & $\begin{array}{l}\text { 20mg Prednisolone } \\
\text { tablet for } 21 \text { days. } \\
\text { patient was lost to } \\
\text { follow up. }\end{array}$ \\
\hline 33 & $\begin{array}{l}\text { Breast lump } \\
\text { and nipple } \\
\text { discharge } \\
\text { since } 2 \text { months }\end{array}$ & $\begin{array}{l}\text { BIRADS-4B, } \\
\text { moderate } \\
\text { suspicion of } \\
\text { malignancy } \\
(10-50 \%)\end{array}$ & $\begin{array}{l}\text { Degenerated cells } \\
\text { admixed with } \\
\text { polymorphs, } \\
\text { histiocytes, } \\
\text { lymphocytes and } \\
\text { cystic } \\
\text { macrophages s/o } \\
\text { acute on chronic } \\
\text { inflammation. } \\
\text { Nipple discharge } \\
\text { of this patient } \\
\text { showed } \\
\text { granulomas in } \\
\text { addition to the } \\
\text { above features. }\end{array}$ & 1 year & $\begin{array}{l}\text { 20mg Prednisolone } \\
\text { tablet for } 21 \text { days. } \\
\text { antibiotic for } 7 \\
\text { days was added } \\
\text { after this as } \\
\text { symptoms } \\
\text { persisted. steroids } \\
\text { tapered. } \\
\text { Patient is symptom } \\
\text { free till date. } \\
\text { (Duration of follow } \\
\text { up -3months) }\end{array}$ \\
\hline 40 & $\begin{array}{l}\text { Breast Lump } \\
\text { for } 1 \text { month }\end{array}$ & $\begin{array}{l}\text { BIRADS-5, } \\
\text { Highly } \\
\text { suggestive of } \\
\text { malignancy } \\
>95 \%\end{array}$ & $\begin{array}{c}\text { Shows } \\
\text { polymorphs, } \\
\text { histiocytes, } \\
\text { lymphocytes and } \\
\text { cystic } \\
\text { macrophages } \\
\text { along with few } \\
\text { granuloma. }\end{array}$ & 4 years & $\begin{array}{l}\text { 20mg Prednisolone } \\
\text { tablet for } 21 \text { days, } \\
\text { tapered to } 10 \text { and } \\
5 \mathrm{mg} \text {. } \\
\text { Patient is symptom } \\
\text { free till date. } \\
\text { (Duration of follow } \\
\text { up- } 5 \text { months) }\end{array}$ \\
\hline 39 & $\begin{array}{l}\text { Breast lump } \\
\text { for } 1.5 \text { months }\end{array}$ & $\begin{array}{l}\text { BIRADS-5, } \\
\text { Highly } \\
\text { suggestive of } \\
\text { malignancy } \\
>95 \%\end{array}$ & $\begin{array}{c}\text { Chronic } \\
\text { inflammatory } \\
\text { lobulitis with few } \\
\text { giant cell } \\
\text { granulomas }\end{array}$ & 3 years & $\begin{array}{l}\text { 20mg Prednisolone } \\
\text { tablet for } 21 \text { days, } \\
\text { tapered to } 10 \text { and } \\
5 \mathrm{mg} \text {. } \\
\text { Patient is symptom } \\
\text { free till date. } \\
\text { (Duration of follow } \\
\text { up- 2months) }\end{array}$ \\
\hline 33 & $\begin{array}{l}\text { Breast lump } \\
\text { with pain for } 1 \\
\text { month. }\end{array}$ & $\begin{array}{l}\text { BIRADS-4B, } \\
\text { moderate } \\
\text { suspicion of } \\
\text { malignancy } \\
(10-50 \%)\end{array}$ & $\begin{array}{l}\text { Focal areas of } \\
\text { microabscess with } \\
\text { granuloma } \\
\text { formation }\end{array}$ & I year & $\begin{array}{l}\text { 20mg Prednisolone } \\
\text { tablet for } 21 \text { days, } \\
\text { tapered to } 10 \text { and } \\
5 \mathrm{mg} \text {. } \\
\text { Patient is symptom } \\
\text { free till date. } \\
\text { (Duration of follow } \\
\text { up- } 4 \text { months) }\end{array}$ \\
\hline 30 & $\begin{array}{l}\text { Breast lump } \\
\text { with } \\
\text { discharging } \\
\text { sinuses for } 1 \\
\text { month }\end{array}$ & $\begin{array}{l}\text { BIRADS-4B, } \\
\text { moderate } \\
\text { suspicion of } \\
\text { malignancy } \\
(10-50 \%)\end{array}$ & $\begin{array}{c}\text { Reparative } \\
\text { granulation tissue } \\
\text { with fibrosis and } \\
\text { areas showing } \\
\text { granuloma } \\
\text { formation. }\end{array}$ & 6 months & $\begin{array}{l}\text { Exenteration of } \\
\text { abscess cavity with } \\
\text { sinus tract } \\
\text { excision. } \\
\text { Followed by } \\
\text { antibiotics } \\
\text { (Amoxy-clav- } \\
625 \mathrm{mg} \text { ) and } \\
\text { prednisolone. }\end{array}$ \\
\hline 27 & $\begin{array}{l}\text { Breast Lump } \\
\text { for } 1.5 \text { months }\end{array}$ & $\begin{array}{l}\text { BIRADS-4B } \\
\text { moderate } \\
\text { suspicion of } \\
\text { malignancy } \\
(10-50 \%)\end{array}$ & $\begin{array}{l}\text { Well-formed } \\
\text { granulomas } \\
\text { comprising of } \\
\text { epitheloid cells, } \\
\text { lymphocytes and } \\
\text { histiocytes. }\end{array}$ & Lactating & $\begin{array}{l}20 \mathrm{mg} \text { Prednisolone } \\
\text { tablet for } 21 \text { days, } \\
\text { tapered to } 10 \text { and } \\
\text { 5mg. Patient is still } \\
\text { on treatment. }\end{array}$ \\
\hline
\end{tabular}


Summary- In the present study, age group varied from 25-42 years with mean age 35 years. The interval of presentation from lactation varied from lactating to 6 years post lactation. Duration of symptoms were ranging from 1 to 2 months. BIRADS grading ranged from $4 \mathrm{~b}$ to 5 .

All the cases were unilateral.

On histopathology all cases show features of chronic inflammation with granuloma formation suggestive of granulomatous mastitis.

\section{Mammographic Spectrum}

Plate 1- 42-year old female presented with lump in left breast for past 1 month.

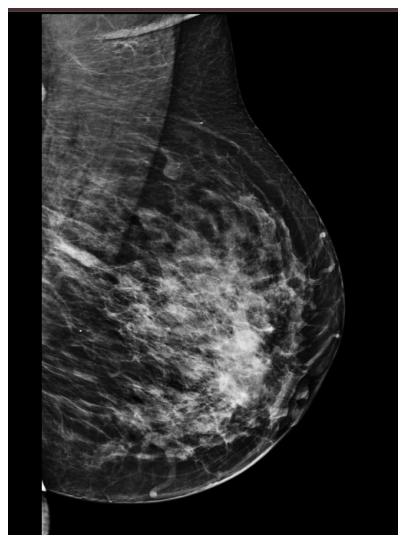

1.1- MLO View

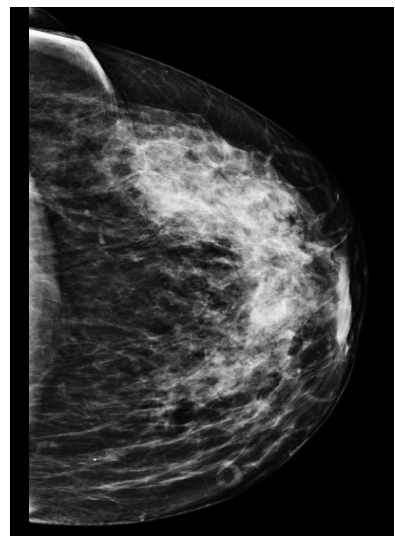

1.2- CC View

Figure 1.1,1.2-Mammography shows asymmetrical increased density in left upper outer quadrant and central region with thickening of skin overlying the NAC and fixed left nipple

Plate 2- 40-year old female presented with lump in left breast for past1 month.

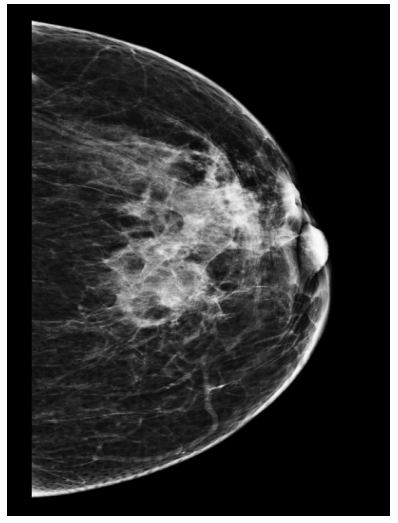

2.1- CC View

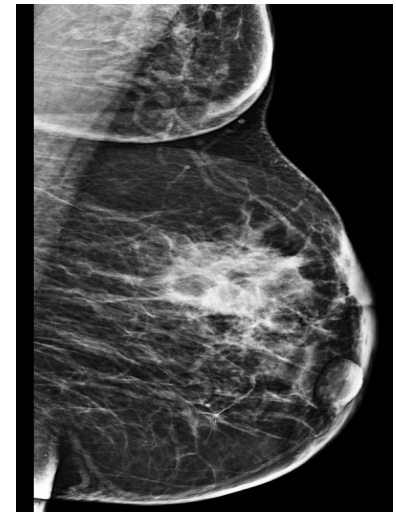

2.2- MLO View

Figure-2.1,2.2-Mammography shows an ill-defined high-density area with architectural distortion in upper outer quadrant with focal hyperdense overlying skin thickening. Accessory breast also noted in MLO view in left axilla.

\section{Ultrasonographic Spectrum}




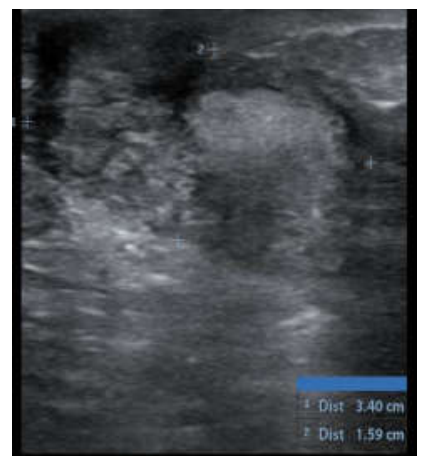

Original Research Article

Figure-3: USG shows heterogeneously hypoechoic lesion with surrounding inflamed echogenic fat and hypoechoic strands in retroareolar region with extension into 2-5 O'clock region.

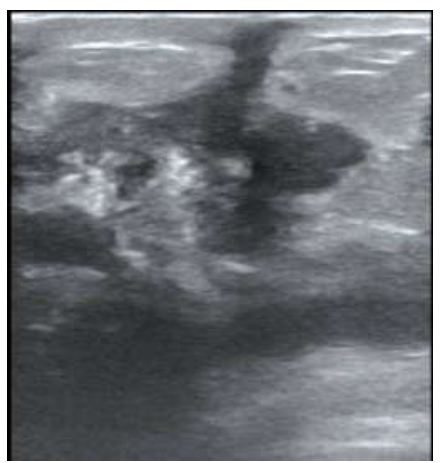

Figure-4: USG shows an ill-defined heterogeneously hypoechoic lesion with surrounding inflamed echogenic fat and hypoechoic strands. A hypoechoic tract seen extending from the lesion upto skin surface in 1-3 O'clock region.

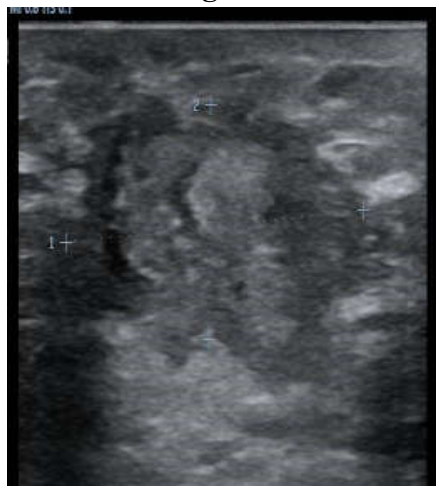

Figure-5: USG shows an ill marinated heterogeneously hypoechoic lesion with surrounding hypoechoic strands in 1-3 O'clock region.

\section{Histopathological Spectrum:}

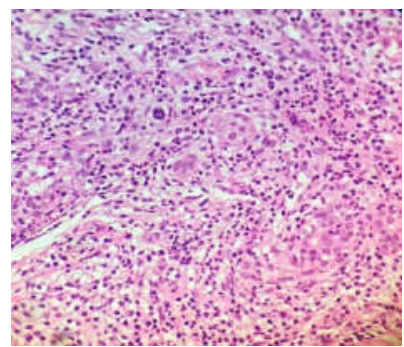

Figure-6: Sections from Tru-cut biopsy specimen show breast tissue with chronic inflammatory lobulitis. Few granulomas with giant cells were seen in the lobules. 
Original Research Article

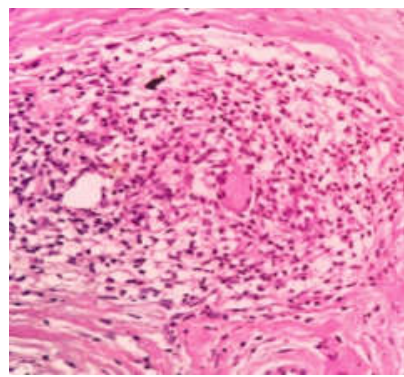

Figure 7- Section from Tru-cut biopsy specimen show dense perilobular chronic inflammatory infiltrates with giant cells and epitheloid cells.

\section{Discussion}

Granulomatous mastitis is a rare entity of unknown etiology. Although initially described nearly 30 years ago, [1] the number of cases in the literature remains small. The clinical diagnosis is difficult with clues from the history, but clinical awareness that this condition can mimic breast cancer in all aspects of the triple assessment process should arouse suspicion [2]. It has been frequently misdiagnosed as breast carcinoma, and many times treated with co-therapy or mastectomy. In our case series all patients presented as breast lump with clinical suspicion of malignancy.

The real incidence of granulomatous mastitis is unknown, with only a few hundred cases reported in the literature [3]. Until now, the largest patient series reported in the literature was that of Yildiz et al. [4], which involved 30 patients with a diagnosis of idiopathic granulomatous mastitis.

The etio-pathology is not well understood but the autoimmune pathology is favoured [5].

The most common signs and symptoms are unilateral breast mass, pain, and skin lesions [6] also present in most of cases in our case study. Clinically, radiologically, and even cytological, it can be confused with malignancy, requiring histopathological examination for a definitive diagnosis [3]. In a case series by Yildiz et al [4], approximately $44.8 \%$ of cases were labelled as BIRADS4 and 5 similar to findings in our case series. In our case series BIRADS grading ranged from $4 \mathrm{~b}$ to BIRADS-5(i.e. moderate to high suspicion of malignancy).

Although granulomatous mastitis usually appears within 6 years after pregnancy, the lesion may develop up to 15 years postpartum [7]. Although most GM cases show association with lactation and pregnancy, a minority of cases have been linked to hyperprolactinemia caused by either dopamine antagonist medications or with intracranial lesions, such as pituitary adenoma. [8]. All cases in our study were presenting within 6 years of lactation and one patient was currently lactating. Our age group corresponds with the study of Going JJ et al [7]. In a case series by Han BK et al, the mammography characteristics of granulomatous mastitis are previously described as normal or as a suspicious mass or a mass suspected of being malignant [9]. In our cases mammographic appearance varied from an ill-defined high-density area with architectural distortion to illdefined lobulated, iso-high density lesions BIRADS 4b5. However, we found that the mammographic density of lesions was usually less as compared to biopsy proven malignant lesions.

In a case report by Van Ongeval $C$ et al, the sonographic appearance of granulomatous mastitis was described as an inhomogeneous, irregular hypoechoic lesion with focal posterior shadowing [10]. The sonographic appearance in our study was predominantly of ill-defined heterogeneously hypoechoic lesion with surrounding hypoechoic strands with some areas of posterior acoustic shadowing and echogenic surroundings showing similarity to malignant lesions. The mammographic appearances are shown in Plate 1 and Plate 2.

Neither mammography nor Doppler sonography plays a significant role in the differential diagnosis of granulomatous mastitis versus or carcinoma. Gray-scale sonography shows findings specific for granulomatous mastitis in some cases, but all cases require histopathologic confirmation for final diagnosis [11]. It should be borne in mind that imaging alone may not be adequate to exclude underlying malignancy or to diagnose GM, necessitating a confirmatory histopathological diagnosis [12]. The sonographic appearances are shown in figures 3,4 and 5 .

Non-caseating and multiple well-defined granulomas distorting the normal breast lobules are the typical features of IGM in histopathological examination [13]. All the patients in our series were followed with HPE diagnosis and revealed granulomatous inflammation. It is a diagnosis of exclusion and in our set up TB has to be 


\section{Original Research Article}

excluded because of high incidence of tuberculosis in India. In all eight cases TB was ruled out using CBNAAT from aspirated samples as standard test. The histopathological appearances are shown in figures 6 and 7.

The optimal treatment approach for IGM has not been established, research limited by the low frequency of the diagnosis [12]. In Hovanessian Larsen et al.'s series, $77 \%$ of patients showed clinical improvement after treatment with corticosteroids (10/13), compared to only $5 \%$ with antibiotics $(2 / 38)$ [14].

Surgical intervention in the form of wide surgical excision was the mainstay of treatment before 1980 [14] and is still performed depending on local expertise and preference. However, multiple surgeries may be required to achieve final remission: 8 of 11 patients in Yau et al.'s series underwent more than 1 surgical intervention, including all 8 women initially treated with incision and drainage [15]. The number of surgical interventions per patient ranged from 1 to 6 (mean 2.8). In some rare cases, mastectomy is performed with breast reconstruction. In our case series seven cases were conservatively managed with course of corticosteroids and short course of antibiotics. One patient was managed with surgical exploration and excision of abscess cavity and sinus tract. Treatment and follow up are mentioned in Table 1.

Limitations of the study: Due to the short study period and very less incidence of the disease, the number of cases remains less with short duration of follow-up.

\section{Conclusion}

Because of its uncommon nature and obscure presentation, idiopathic granulomatous mastitis presents a diagnostic challenge. The clinical presentation, radiological findings and pathological findings have to be correlated to reach the diagnosis. Breast clinicians and breast radiologists should be aware of this entity to avoid misdiagnosis as malignancy.

\section{What the study adds to the existing knowledge?}

This study outlines the sono-mammographic and pathological features where a diagnosis of granulomatous mastitis should be suspected and sought especially in younger females. Though surgical excision was mainstay of treatment previously, conservative management was effective in majority of the present cases. So a trial with corticosteroids with or without antibiotics should be tried before proceeding with surgical interventions. But this is still a poorly

understood disease and more research needs to be done to find the etiology as well as optimum management

\section{Author's contribution}

All authors were actively involved in manuscript preparation and data collection, analysis.

Dr. Divya Pandey: Imaging and diagnostic aspects

Dr. Anjum Syed: Imaging and diagnostic aspects

Dr. Bina Ravi: Clinical and Surgical aspects

Dr. Nilotpal Chowdhury: Pathological aspects

Dr. Aakriti Kapoor: Imaging and diagnostic aspects

Dr. Surabhi Mehrotra: Imaging and diagnostic aspects

Dr. Priyanka Gupta: Imaging and diagnostic aspects

Dr. Pranoy: Pathological aspects

\section{Conflict of Interest - No}

\section{References}

1. Kessler E, Wolloch Y. Granulomatous mastitis: a lesion clinically simulating carcinoma. Am J Clin Pathol 1972;58(6):642-646. doi: 10.1093/ajcp/58.6.642

2. Heer R, Shrimankar J, Griffith CDM. Granulomatous mastitis can mimic breast cancer on clinical, radiological or cytological examination: a cautionary tale. The breast. 2003;12(4):283-286. doi: https://doi.org/10.1016/S0960-9776(03)00032-8

3. Pelin Seher Oztekin, Gamze Durhan, Pinar Nercis Kosar, Serap Erel, Sema Hucumenoglu. Imaging Findings in Patients with Granulomatous Mastitis. Iran J Radiol. 2016;13(3):e33900. doi: 10.5812/iranjradiol.33900

4. Yildiz S, Aralasmak A, Kadioglu H, Toprak H, Yetis $\mathrm{H}$, Gucin $\mathrm{Z}$, et al. Radiologic findings of idiopathic granulomatous mastitis. Med Ultrason. 2015;17(1):3944. doi: 10.11152/mu.2013.2066.171.rfm.

5. Erhan Y, Veral A, Kara E, Özdemir N, Kapkac M, Özdedeli E et al. A clinicopthologic study of a rare clinical entity mimicking breast carcinoma: idiopathic granulomatous mastitis. Breast 2000; 9(1):52-56. doi: https://doi.org/10.1054/brst.1999.0072

6. Memis A, Bilgen I, Ustun EE, Ozdemir N, Erhan Y, Kapkac M. Granulomatous mastitis: imaging findings with histopathologic correlation. Clin Radiol. 2002;57(11):1001-1006.

doi: https://doi.org/10.1053/crad.2002.1056

7. Going JJ, Anderson Ti, Wilkinson 5, Chetty U. Granulomatous lobular mastitis. J Clin Pathol. 1987;40(5):535-540. doi: 10.1136/jcp.40.5.535

Pathology Update: Tropical Journal of Pathology \& Microbiology Available online at: www.medresearch.in 646 | P a g e 
Original Research Article

8. Nikolayev A, Blake CN, Carlson DL. Association between Hyperprolactinemia and Granulomatous Mastitis. Breast J. 2016;22(2):224-231. doi: 10.1111/tbj.12552.Epub 2015 Dec 26.

9. Han BK, Choe YH, Park JM, Moon WK, Ko YH, Yang JH, et al. Granulomatous mastitis: mammographic and sonographic appearances. AJR Am J Roentgenol. 1999;173(2):317-320. doi: 10.2214/ajr.173.2.10430126.

10. Van Ongeval C, Schraepen T, Van Steen A, Baert AL, Moerman P. Idiopathic granulomatous mastitis. Eur Radiol. 1997; 7:1010-1012. doi: 10.3349/ymj.2006.47.1.78

11. Engin G, Acunas G, Acunas B. Granulomatous mastitis: gray-scale and color Doppler sonographic findings. J Clin Ultrasound. 1999;27(3):101-106.
12. Gautier N, Lalonde L, Tran-Thanh D, El Khoury M, David J, Labelle $\mathrm{M}$, et al. Chronic granulomatous mastitis: Imaging, pathology and management. Eur J Radiol. 2013;82(4):165-175. doi: 10.1016/j.ejrad. 2012.11.010.

13. Tavassoli FA. Pathology of the breast. Stamford, Connecticut, Appleton and Lange 1999:793.

14. Hovanessian Larsen LJ, Peyvandi B, Klipfel N, Grant E, Iyengar G. Granulomatous lobular mastitis: imaging, diagnosis, and treatment. Am J Roentgenol. 2009;193(2):574-581. doi: 10.2214/AJR.08.1528.

15. Yau FM, Macadam SA, Kuusk U, Nimmo M, Van Laeken N. The surgical management of granulomatous mastitis. Ann Plastic Surg. 2010;64(1):9-16. doi: 10.5152/turkjsurg.2017.3439

\section{How to cite this article?}

Pandey D, Syed A, Ravi B, Chowdhury N, Kapoor A et al. Idiopathic granulomatous mastitis: a diagnostic challenge. Trop J Path Micro 2019;5(9):640-647.doi:10.17511/jopm.2019.i09.05. 